\title{
Comprehensive Investigation on Hydrogen and Fuel Cell Technology in the Aviation and Aerospace Sectors
}

\author{
Ahmad Baroutaji ${ }^{1(*)}$, Tabbi Wilberforce ${ }^{2}$, Mohamad Ramadan $^{3}$, Abdul Ghani Olabi ${ }^{4,5}$ \\ (1) School of Engineering, Faculty of Science and Engineering, University of Wolverhampton, Telford, UK \\ (2) Institute of Engineering and Energy Technologies, University of the West of Scotland, UK \\ (3) International University of Beirut, PO Box 146404, Beirut, Lebanon \\ (4) Sustainable and Renewable Energy Engineering Department, University of Sharjah, P.O. Box: 27272, \\ Sharjah, United Arab Emirates \\ (5) School of Engineering and Applied Science, Aston University, Aston Triangle, Birmingham B4 7ET, UK
}

\begin{abstract}
The world energy consumption is greatly influenced by the aviation industry with a total energy consumption ranging between $2.5 \%$ and $5 \%$. Currently, liquid fossil fuel, which releases various types of Greenhouse Gas (GHG) emissions, is the main fuel in the aviation industry. As the aviation industry grows rapidly to meet the requirements of the increased world population, the demand for environmentally friendly power technology for various applications in the aviation sector has been increased sharply in recent years. Among the various clean power sources, energy obtained from hydrogen is considered the future for energy generation in the aviation industry due to its cleanness and abundance. This paper aims to give an overview of the potential aviation applications where hydrogen and fuel cell technology can be used. Also, the major challenges that limit the wide adoption of hydrogen technology in aviation are highlighted and future research prospects are identified.
\end{abstract}

Keywords: Hydrogen, Fuel cells, Aviation, Renewable Energy, Clean Power 


\begin{tabular}{|ll|}
\hline Nomenclature & \\
$\mathrm{GHG}$ & Greenhouse Gas \\
$\mathrm{CO}_{2}$ & Carbon dioxide \\
$\mathrm{SO}_{2}$ & Sulphur dioxide \\
$\mathrm{CO}$ & Carbon monoxide \\
$\mathrm{APU}$ & Auxiliary Power Unit \\
$\mathrm{LH}_{2}$ & Liquid hydrogen \\
$\mathrm{H}_{2}$ & Hydrogen \\
$\mathrm{H}_{2} \mathrm{O}$ & Water vapour \\
$\mathrm{NO}_{\mathrm{X}}$ & Nitrogen oxides \\
$\mathrm{O}_{3}$ & Ozone \\
$\mathrm{CH}$ & \\
$\mathrm{PEMFC}$ & Methane \\
$\mathrm{SOFC}$ & Proton Exchange Membrane Fuel Cell \\
$\mathrm{AUV}$ & Solid Oxide Fuel Cell \\
$\mathrm{BoP}$ & Unmanned Aerial Vehicles \\
$\mathrm{AFC}$ & Balance of Plant \\
$\mathrm{PEM}$ & Alkaline Fuel Cells \\
$\mathrm{SPE}$ & Proton Exchange Membrane \\
\hline
\end{tabular}

\section{Introduction}

Nowadays, the air transport community contributes significantly to the socio-economic development of various countries around the world. The capacity of transport by air has increased significantly over the last two decades and it is expected to grow by around 5\% annually until 2030 [1]. Inevitably, this will result in increasing the number of working jets. According to the Boeing current market outlook [2], it is projected that by 2036 there will be around 47000 working jets compared to 23000 in 2016. The weight that a plane can hold is huge and it varies depending on the total capacity of the plane but the average total weight in most commercial flights is approximately 640 tons [3]. In order for a plane to carry such a big weight, huge engines, which consume considerable amounts of fuel, are needed. The high demand for aviation fuel to support this huge load comes with various challenges and 
consequences pertaining to safety, cost, specific energy and efficiency. Most fuels used in the aviation industry are currently fossil based petroleum commodities. The fuel that can be used in the aviation industry must contain a combination of different properties such as high specific heat capacity, high energy density, good atomization, fast evaporation, excellent burning characteristics, low viscosity, high lubricity, low freezing point, good chemical and thermal stability, and low impact to the environment [3], [4]. Among the various types of fuel commodities, kerosene is the cheapest and the most used fuel in the aviation industry. Kerosene is made up of $35 \%$ alkenes, $60 \%$ cyclic alkanes, $15 \%$ aromatics [3]. Despite it is a cheap fuel, the kerosene has a significant impact on the environment as it releases different GHG emissions and for this scientists are currently working earnestly hard to find a clean alternative to it. The global aviation industry produces around $12 \%$ of carbon dioxide $\left(\mathrm{CO}_{2}\right)$ emissions generated by the transport sector [3]. In 2015, it was reported that nearly 781 million tonnes of $\mathrm{CO}_{2}$ were generated from flights [5]. GHG emissions of the kerosene are $\mathrm{CO}_{2}$ and sulphur dioxide $\left(\mathrm{SO}_{2}\right)$ [6]. $\mathrm{SO}_{2}$ is considered a very dangerous emission due to its role in the formation of acid rain [6]. The environmental effects of the kerosene are the crucial factors for seeking a new clean replacement of the fossil commodities for aviation applications. Hydrogen and fuel cell technology have a great potential to be used as a power source for various applications in the aviation industry [7]-[16]. The scientific community is currently championing several researchers into hydrogen as a source of power because it is readily available, has good specific energy properties and also friendly to the environment [3], [4], [17]. The usage of hydrogen in aviation sector can be categorised into two main routes; the first is the use of hydrogen as a replacement to kerosene for big aeroplanes, and the second is using fuel cells in place of jet engines for small aeroplanes [18]. The use of fuel cell technology for aircraft still in its early days but it is receiving increased attention every day from leading aircraft manufactures. Airbus and Boeing are currently exploring the possibility of using fuel cell technology to power the 
Auxiliary Power Units (APUs) of their aircraft that used to be powered by diesel engines. Also, the fuel cells have the potential to be used in place of batteries to power other devices and systems in aircraft. For instance, they can be used for cabin pressurisation, environmental control system, lighting, and instrumentation in the cockpit, wing anti-ice protection, control surface and landing gear actuation.

It is projected that hydrogen and the fuel cell technology will continue to receive interest and application in the aviation. A fuel-cell-powered commercial aircraft might become a reality within a decade or two after solving some major problems in the field related to high cost of the technology, hydrogen production, storage, and refuelling infrastructures, aircraft design, and so on. The aim of the current paper is to present the current status of hydrogen and its technology for the aviation and aerospace industry and also to highlight the main challenges that need attention in order to see wider adoption of these technologies in the sector.

\section{Hydrogen as a propulsion fuel}

Using hydrogen in aeronautical applications dated back to the late 18th century where it was used for hydrogen balloon and then, at early twenty century, for rigid airship such as Zeppelin due to its superb bouncy feature [19]. Since then, different projects were launched in many countries to evaluate and develop hydrogen-powered aircraft, which use hydrogen as a propellant, such as Suntan (USA-1956), Tupolev Tu-155 (Soviet Union- 1988), CRYOPLANE (Europe- 2000), HyShot (Australia- 2001), NASA X-43 (USA- 2004), Phantom Eye (USA2013). In addition to its usage for aeronautics, hydrogen is the primary fuel for rockets because it has high specific energy. The fuel tank of a rocket is normally filled with liquid hydrogen $\left(\mathrm{LH}_{2}\right)$ and liquid oxygen $(\mathrm{LO})$ that react together and gives a lot of power to thrust the rocket up. For decades, cold $\mathrm{LH}_{2}$ was used by NASA as rocket fuel for many of its space shuttle vehicles including Centaur and Apollo [20]. Hydrogen was adopted as a fuel by most of rocket engines developers around the world such as RL10 (Aerojet Rocketdyne- USA), LE-5 
(Mitsubishi- Japan), HM7B (Snecma- France), YF-73 (CALT- China), KVD-1 (Russia), CE20 (HAL- India) [19].

The usage of hydrogen as a fuel in place of fossil commodities has some challenges but its advantages outweigh the disadvantages. The hydrogen has the highest energy per unit mass compared to any other fuel obtained chemically. Its energy density is 2.5 times bigger than that of kerosene [21]. Using hydrogen as an aviation fuel would eliminate most of the GHG emissions including all carbon-based emissions, soot, and sulphur oxides [22]. The main byproducts of hydrogen in a combustion process are water vapour $\left(\mathrm{H}_{2} \mathrm{O}\right)$ and nitrogen oxides $\left(\mathrm{NO}_{\mathrm{X}}\right)$ [23]. $\mathrm{NO}_{\mathrm{x}}$ emissions are associated with the formation of smog, acid rain and particulate matter. Furthermore, $\mathrm{NO}_{\mathrm{x}}$ emissions result in the production of ozone $\left(\mathrm{O}_{3}\right)$ which is a climate warming gas and have negative effects on tropospheric $\mathrm{O}_{3}$ and stratospheric $\mathrm{O}_{3}$ [22], [24]. However, the amounts of $\mathrm{NO}_{\mathrm{x}}$ emissions released from burning hydrogen are extremely low compared to those released when burning kerosene [25]. Generally, the overall reduction of $\mathrm{NO}_{\mathrm{x}}$ when using hydrogen fuel is due to the fact that the water vapour generated from burning hydrogen absorb most of the energy released from the combustion process and thus reduce peak combustion temperatures preventing the formation of $\mathrm{NO}_{\mathrm{x}}$ [26]. The water vapour contributes to the formation of contrails which also has global warming effects. The percentage of water vapour increases when hydrogen is used in place of petroleum-based fuels in aeroplanes [21]. Despite that burning hydrogen produces a larger amount of water vapour, which is considered as a GHG, it still provides a significant reduction in the net GHG emissions as a jet fuel compared to kerosene [4], [27]. Furthermore, adoption of hydrogen as a jet fuel can provide long term stable level of the fuel prices and also enhance the reliability of the fuel supply because it can be obtained from different types of sources and this reduces the reliance on fossil fuel concentrated in only few regions around the world [21], [27]. Thus, hydrogen is deemed suitable for the aviation industry because it is capable of providing clean, reliable and 
affordable energy supply that has extremely low pollutant emissions and thus has a low impact on the environment [23].

In order for hydrogen to be viable for the aviation industry, its volumetric density or energy density per unit volume must be increased [28], [29]. Comparing with kerosene, four times bigger volume of $\mathrm{LH}_{2}$ is needed to deliver the same amount of energy [19]. However, despite this drawback, it has been reported that the hydrogen-powered aircraft are more weight efficient and involve lower operating costs than those aircraft powered with kerosene [19]. Generally, using hydrogen as a jet fuel necessitates modifying the design of both aircraft and engines. $\mathrm{LH}_{2}$ used in hydrogen-powered aircraft must be kept at very low temperatures and for this it can only be stored in highly-insulated tanks and not in the wings which have restricted space to accommodate $\mathrm{LH}_{2}$ and cannot be insulated properly. With the huge volume requirements of the hydrogen fuel tanks, aircraft design needs to be modified with a greater volume and heavier fuselage, which is the best location to place $\mathrm{LH}_{2}$ fuel tanks, as shown in Figure 1 [23]. For short-to-medium range aircraft, the hydrogen tanks could be placed above the passenger cabin while for the long-range aircrafts the hydrogen is stored in two big integral tanks; one of them is located directly behind the cockpit and the second is placed at the far aft of the passenger cabin [30]. The configuration of hydrogen tanks has a significant impact on the energy efficiency of hydrogen-powered aircraft [30]. The top-tank design, used in short-tomedium range aircraft, may increase the energy use by 6-19\% due to the greater weight of this type of tanks [30]. On the other hand, the integral design, suitable for long-range aircraft, can increase the energy efficiency by $12 \%$ [30]. Thus, it can be concluded that hydrogen fuel is more suitable for long-range aircraft. Since the fuselage of hydrogen-powered aircraft is used to store hydrogen tanks, a heavier and bigger fuselage is needed to support the loads generated from these tanks. The mass of fuselage in hydrogen-powered aircraft is almost $6 \%$ bigger than the normal aircraft [27]. Additionally, since the wings in the hydrogen-powered aircraft are no 
longer used to store fuel, the wings could be designed to be smaller in terms of area and span. However, the weight of wings should be increased when using hydrogen in order to enhance their structural integrity against bending and vibrations generated by aerodynamic forces [30]. The smaller wings and greater fuselage of hydrogen aircraft may affect the aerodynamic efficiency negatively [21]. In addition to changing the aircraft design, the engine has to be changed when converting into hydrogen due to variation in the combustion gases and properties between the kerosene and hydrogen. Smaller engines can be used for hydrogen fuel [27]. The changes in aircraft and engine designs when using hydrogen entail an increase in the production and maintenance costs which could reach up to $25 \%$ [21].

\section{$3 \quad$ Hydrogen fuel cell for aviation applications}

A hydrogen fuel cell is an electrochemical device that generates electricity via an electrochemical reaction between hydrogen and oxygen. Fuel cells are silent, produce little vibrations and produce no NOx emissions which make them very attractive for wide range of applications. Among the various types of fuel cells devices, Proton Exchange Membrane Fuel Cell (PEMFC) and Solid Oxide Fuel Cell (SOFC) were mostly considered for the aviation applications. SOFC operates at high temperature and uses a dense ceramic layer as an electrolyte while PEMFC operates at low temperature and employs proton conducting membrane as the electrolyte. A summary of the working principles of these types of fuel cells is presented in Figure 5. Hydrogen fuel cells could be used on-board of aircraft to power different items and systems that are currently powered by batteries such as emergency door system, floor escape path lighting, Emergency Locator Transmitter (ELT), Flight Data Recorder (FDR), and Cockpit Voice Recorder (CVR). The main aviation applications where fuel cells have been tested are reviewed in the next sections 


\subsection{APU in aircrafts}

APU of aircraft is a small gas turbine which functions as a source of electricity and compressed air for the operation of other components in the aircraft, such as jet engines and environmental systems, when the main engines are not running. APU is used as a back up to internal power during cruising and as the main source of power to the aircraft during stationary as it supplies the required power for air conditioning and lighting in the aircraft. It also supports the starting up of the main aircraft engines. APU is turned on when the aircraft is taxing from the runway to the gate or the parking [31]. Around $20 \%$ of aircraft emissions are from traditional APU powered with gas turbines [32]. One of the targets set by the Advisory Council for Aviation Research in Europe (ACARE) is the emission-free taxing phase. Such a target can be achieved by implementing a clean power source to run APU during taxing. Fuel cell devices have been identified as a suitable source to power APU and thus reducing the fuel consumption during aircraft taxing phase [17]. The by-products of fuel cells including water and heat can be channelled to other components in the aircraft [33]. Besides their environmental advantages, fuel cell powered APU can help also in reducing the noise levels [34].

Fuel cell systems could be used in place of the traditional APU or combined with them to form a hybrid APU system [34]. Both PEMFC and SOFC can be used for AUP systems [35]. However, SOFC is more favourable for aircraft applications particularly for powering APU [34]. SOFC is more tolerant of fuel impurities and can operate using hydrogen generated from kerosene reforming [34]. Additionally, the high operating temperature of SOFC allows the internal reforming process of jet fuel and increases the efficiency [34]. However, the weight of the SOFC powered APU is greater than PEMFC or the traditional APUs because it requires bigger balance-of-plant (BoP) items such as reformer, compressor, pumps, heat exchangers and so on [34]. PEMFC can only be used for powering the APU if the source of hydrogen is installed on the aircraft. 
Main aircraft manufacturers, including Airbus [36] and Boeing [37], are currently running projects aiming for using electrical power generated by hydrogen fuel-cell devices to power all non-propulsion systems in the aircraft. Such an approach might help in reducing the loads on the main engines and thus the planes become more fuel-efficient [19]. Boeing stated in its report that using solid oxide fuel cells in APU will reduce the fuel consumption during cruising and stationary by $40 \%$ and $75 \%$, respectively [38]. The CRYOPLANE European project also estimated that SOFC APU will reduce aircraft ground $\mathrm{NO}$ x by $80 \%$ [39].

In summary, using fuel-cell-powered APU can be considered as a great solution for reducing fuel consumption, pollution and GHG emissions.

\subsection{Ground Support Equipment (GSE)}

With the increased interest in improving the air quality around airports, fuel cells devices have received increased attention due to their potential in powering different Ground Support Equipment (GSE) and other ground vehicles working in the airports, such as passenger shuttles and refuelling trucks, in the near future [40].

GSE or aircraft handling devices are used to service passengers, cargo, facilities and aircraft while they are in the airport between flights. GSE contain different service systems such as air start unit of the engine, air conditioning unit, cargo loaders, pushback track, stairs for passengers, baggage tractors, trolleys, etc. Each of these devices has different power requirements. Air start unit is considered as the most energy consuming device among all the aircraft handling devices as it consumes approximately $450 \mathrm{~kW}$ [41]. The next energy consuming device is the pushback truck which is also approximately $200 \mathrm{~kW}$. A number of other aircraft handling devices, such as forklifts, baggage tractors, water trucks, deck loaders and air conditioning units, have a power range between $10 \mathrm{~kW}$ to $50 \mathrm{~kW}$ [41].

Today, many of GSE working in the airport are powered by hydrogen fuel cells. Department of Energy (DOE) has announced that around 250 million US dollars will be used to deploy fuel 
cells for baggage vehicles at airports [42]. The medium size fuel cell powered forklifts have been already tested in major airports such as Toronto Pearson, Hamburg, and Munich airports [43]. These forklifts incorporate many advantages such as low noise, no emissions and less maintenance. They have almost the same dimensions as traditional batteries powered ones but they do not require battery swapping which is very challenging for most conventional forklifts. Additionally, refuelling time was seen as a major advantage for fuel cell powered forklift over battery ones as it can be completed within minutes while recharging the battery needs hours [44]. The fuel cells can also be used for more than eight hours without requiring any refuelling. Thus, it can be concluded that replacing traditional batteries with fuel cells in forklifts is viable economically with respect to the initial capital cost as well as the operating costs. The Danish airport is currently using luggage trolleys that functions using fuel cells. In 2015, FedEx has rolled out the first fuel cell powered GSE cargo tractors that can pull around 15 tonnes of cargo [45].

In addition to GSE applications, the fuel cells are used to power the airport vehicles such as passenger buses. In Tokyo, some of the buses working on the route between Tokyo central and Tokyo airport are a hydrogen fuel cell/battery hybrid system [46]. International Airport in Hawaii set a plan to use a hybrid fuel cell/ battery bus to shuttling passengers between airport terminals and the car rental facility [47].

\subsection{Unmanned Aerial Vehicles (UAVs) and passengers aircraft}

Currently, most of Unmanned Aerial Vehicles (UAVs) are powered by batteries because the conventional power sources, such as reciprocating engines and gas turbines, exhibit very low efficiency for small-scale vehicles. However, the batteries have a low energy density, i.e. low energy per unit mass, which might lead to a significant increase in the weight of UAV if longer flight time, or greater endurance, is required. Fuel cell has been regarded as a possible new power source alternative to existing batteries. Belmonte et al [48] compared the performance 
of batteries and fuel cells with respect to powering UAVs. The authors reported that the cost is the most attractive factor of battery-powered UAV as it is almost half the price of the fuel cell. However, increasing the weight of the battery required to achieve a long flying time has been reported as a limiting factor of battery-powered UAV. The main advantage of the fuel cells for powering UAV includes allowing extended mission time and distance due to superior energy density, providing quiet and reliable operation, reducing lithium battery charging and transport obstacles [49]. PEMFCs are preferred for UAVs applications as they can operate at low temperature and this means smaller BoP requirements. In 2005, AeroVironment has developed the first fuel cell UAV [50]. The plane, that has a wingspan of $15 \mathrm{~m}$, was powered using a PEMFC propulsion system and managed to complete more than one hour of flying using only liquefied hydrogen. Following that in 2006, Bradley et al [51] designed and tested a fuel cell powered UAV using compressed hydrogen. With a wingspan of $6.58 \mathrm{~m}$ and a total mass of $16.4 \mathrm{~kg}$, the authors demonstrated that the plane can be powered using a $500 \mathrm{~W}$ PEMFC. Currently, there are considerable research efforts worldwide to design, develop, and construct fuel cell powered UAV. These efforts have resulted in a significant increase in endurance which exceeded $48 \mathrm{~h}$ [52]. Reducing the weight of fuel cells, improving their reliability and durability, speeding their startup, and increasing their power density will make the fuel cell technology more attractive for UAV [53]. A list of fuel-cell-powered UAV with fuel cell type, storage method and endurance is presented in Table 6.

The fuel cell technology has also been studied as a potential power source to manned aircraft after the 20th century [17]. The first successful fuel cell powered light manned aircraft has been tested in 2008 by Boeing Research \& Technology Europe (BR\&TE) [54]. A two-seat light aircraft with a $16.3 \mathrm{~m}$ wingspan, which has been powered by PEMFC, has successfully completed a 20 minutes flight at a speed of $100 \mathrm{~km} / \mathrm{h}$ [54]. In 2016, a research group from DLR German aerospace centre developed and tested a fuel cell powered four-seat passenger aircraft 
namely HY4 [55]. A PEMFC, assisted by a lithium battery to meet the requirements of peak loads during take-off and climbing, was able to provide the required power to run HY4 that has a maximum weight of $1500 \mathrm{~kg}$ and average cursing speed of $145 \mathrm{~km} / \mathrm{h}$.

\subsection{Space Applications}

For a long time, NASA has used fuel cell technology as a power source and energy storage device in the space shuttles. Onboard fuel cell power plants in space shuttle generate all the electrical power required for the vehicle from launch through landing rollout [56]. The fuel cell power system is integrated with several subsystems responsible for the distribution of reactants, cooling of fuel cell system, storing of generated water, and distribution of electrical power. The water generated during the fuel cells operation is usually used for drinking by the astronauts. The first use of fuel cell by NASA dated back to 1965 in the Gemini V spacecraft. PEMFC was used as the main power source and it was integrated with silver-zinc batteries to meet the peak loads. The Gemini fuel cell system was subsequently used on six manned flights including Gemini 7, 8, 9, 10, 11 and 12 [57], [58]. In 1963, Alkaline Fuel Cells (AFC) was selected for the Apollo mission. The AFC stack consisted of 31 individual fuel cells operated at a temperature of $206^{\circ} \mathrm{C}$ and connected in series to generate a maximum output power of 2300 watts [57]. The use of Apolo fuel cell was expanded to include all Apollo missions, the Apollo/Soyuz mission and Skylab. AFC and PEMFC are the main technologies used by NASA for energy storage applications. NASA has replaced batteries with fuel cells in almost all manned missions [57]. Fuel cells are preferred over batteries for manned missions because such missions require primary energy storage with longer discharge times and higher power levels and these requirements can be better met using fuel cell technology [57].

\section{Hydrogen production and storage}

Despite the hydrogen can be considered as carbon-free fuel, the emissions generated during its production might be very high based on the production method [4]. Thus, the full 
environmental benefits of using hydrogen as a fuel for applications in aviation and aerospace industries require generating the hydrogen using clean and renewable sources. Also, with its low volumetric density, storing hydrogen onboard of aircraft forms a big challenge for the hydrogen-powered aircraft. Due to their significant role in advancing the hydrogen for various aviation applications, the main hydrogen production and storage technologies are reviewed in this section.

\subsection{Overview of hydrogen production technologies}

Hydrogen is the most common element on the earth but it does not exist alone [17]. The generation of hydrogen usually occurs by removing the other elements it combines with [17]. The hydrogen can be obtained from several feedstocks including fossil fuel, such as coal and natural gas, as well as renewables sources, such as water and biomass [59]. Obtaining hydrogen from fossil fuel is a matured approach. Around $90 \%$ of the global hydrogen demand is currently produced from fossil fuel including natural gas and coal [19]. There are two main routes for obtaining hydrogen from natural gas including steam reforming and partial oxidation processes [59]. In the steam reforming process, a natural gas, such as methane $\left(\mathrm{CH}_{4}\right)$, and water vapour are transformed into carbon monoxide (CO) and hydrogen through an endothermic reaction, known as steam reforming, as shown in Equation 1 [3]

$$
\mathrm{CH}_{4}+\mathrm{H}_{2} \mathrm{O}+\text { heat } \rightarrow \mathrm{CO}+3 \mathrm{H}_{2}
$$

The $\mathrm{CO}$ produced as a by-product can further be transformed into $\mathrm{CO}_{2}$ and hydrogen by water gas shift reaction shown in Equation 2 [3]

$$
\mathrm{CO}+\mathrm{H}_{2} \mathrm{O} \rightarrow \mathrm{CO}_{2}+\mathrm{H}_{2}+\text { heat of reaction }
$$

In the partial oxidation method, which is an exothermic process, there is a partial burning of methane with oxygen gas and this generates $\mathrm{CO}$, hydrogen, and heat as shown in Equation 3 [3] 


$$
\mathrm{CH}_{4}+1 / 2 \mathrm{O}_{2} \rightarrow \mathrm{CO}+2 \mathrm{H}_{2}+\text { heat of reaction }
$$

The water gas shift reaction, Equation 2, is then used to convert $\mathrm{CO}$ to $\mathrm{CO}_{2}$ and hydrogen.

There are several methods for converting coal to hydrogen through an endothermic gasification process such as fixed bed gasifier, fluidized bed reactor, entrained flow gasifier, and plasma gasifier [60]. For most gasification reactions, the fuel and agents for the gasification are transformed into a mixture of $C O$ and hydrogen as demonstrated in Equation 4 [3]

$$
\mathrm{C}_{(\mathrm{s})}+\mathrm{H}_{2} \mathrm{O}+\text { heat } \rightarrow \mathrm{CO}+\mathrm{H}_{2}
$$

The production of hydrogen from fossil fuel is always associated with emitting $\mathrm{CO}_{2}$ and $\mathrm{CO}$ which causes air pollution. The negative effects of these gases on living organisms formed the motivation towards developing a technology to extract hydrogen from a clean and renewable source such as water and biomass [61].

The separation process of water into oxygen and hydrogen is known as electrolysis and it is conducted by means of electric energy via a redox (oxidation-reduction) reaction [62]. Equation 5 shows the chemical equation for water electrolysis [3]

$$
\mathrm{H}_{2} \mathrm{O}+\text { electricity } \rightarrow \mathrm{H}_{2}+1 / 2 \mathrm{O}_{2}
$$

The electrolysers could be either low temperatures such as alkaline and Proton Exchange Membrane (PEM) electrolysers; or high temperature such as solid oxide electrolyser. The lowtemperature electrolysers often operate at temperatures below $100^{\circ} \mathrm{C}$ while the hightemperature ones function at higher temperatures up to $1000^{\circ} \mathrm{C}$ [63]. In an alkaline electrolysis, the water in the cathode consumes electrons to form hydrogen. The hydroxide ions flow through the solution in the direction of the anode and during this process the electron is released. Equations 6-8 show the chemical equation for alkaline electrolysis [3].

Cathodic reaction: $2 \mathrm{H}_{2} \mathrm{O}+2 e^{-} \rightarrow \mathrm{H}_{2}+2 \mathrm{OH}^{-}$

Anodic reaction: $2 \mathrm{OH}^{-} \rightarrow 1 / 2 \mathrm{O}_{2}+\mathrm{H}_{2} \mathrm{O}+2 e^{-}$ 
Overall reaction: $\mathrm{H}_{2} \mathrm{O} \rightarrow 1 / 2 \mathrm{O}_{2}+\mathrm{H}_{2}$

PEM electrolyser contains a Solid Polymer Electrolyte (SPE) to conduct protons between the cathode and anode of the electrolyser. The high ionic conductivity of SPE makes the efficiency of PEM electrolyser higher than the alkaline one [62]. The main chemical reactions that occur in a PEM electrolyser are shown in Equations 9-11 [3]

Cathodic reaction: $2 \mathrm{H}^{+}+2 e^{-} \rightarrow \mathrm{H}_{2}$

Anodic reaction: $\mathrm{H}_{2} \mathrm{O} \rightarrow 1 / 2 \mathrm{O}_{2}+2 \mathrm{H}^{+}+2 e^{-}$

Overall reaction: $\mathrm{H}_{2} \mathrm{O} \rightarrow 1 / 2 \mathrm{O}_{2}+\mathrm{H}_{2}$

In a solid oxide electrolyser that operates at high temperatures typically between 500 and $850{ }^{\circ} \mathrm{C}$, water is reduced, in the cathodic region, to generate hydrogen and oxygen ions. The hydrogen gas is collected from the cathode, while the oxygen ions are transferred through a dense electrolyte to the anode side to produce oxygen. The main reactions taking place in solidoxide electrolyser are presented in Equations 12-14

Cathodic reaction: $\mathrm{H}_{2} \mathrm{O}+2 e^{-} \rightarrow \mathrm{H}_{2}+\mathrm{O}^{2-}$

Anodic reaction: $O^{2-} \rightarrow 1 / 2 O_{2}+2 e^{-}$

Overall reaction: $\mathrm{H}_{2} \mathrm{O} \rightarrow 1 / 2 \mathrm{O}_{2}+\mathrm{H}_{2}$

In addition to electrolysis technology, hydrogen can be produced from water via thermochemical water splitting processes that use heat from solar power or wasted heat of nuclear power reactions to drive a series of chemical reactions for splitting water into hydrogen and oxygen [64].

The second main renewable source of hydrogen is biomass resources such as agriculture residues, animal wastes, and organic municipal solid waste [65]. Biomass gasification process, which involves using heat, steam, and oxygen together without combustion, is normally used to extract hydrogen from these organic materials. 
A comparison of the main technologies used for the hydrogen production, excluding those technologies that are still at early stages of research such as microbial biomass conversion and photobiological, is presented in Table 1 and Table 2. Different research and development activities that can lead to further advancement of these technologies are also presented in Table 3.

\subsection{Overview of hydrogen storage technologies}

Despite the potential benefits of using hydrogen as a fuel for the aviation industry, its low density, approximately $0.089 \mathrm{~kg} / \mathrm{m}^{3}$ at standard temperature and pressure, and associated storage problems continue to remain an attractive field for research and developments. With the constraints imposed by aircraft weight and volume, it is challenging to store, produce and use hydrogen efficiently on aircraft. Storage of hydrogen is often categorised into two main sections; physical and chemical storage as shown in Figure 2. Hydrogen can be stored as a pressurised gas, cryogenic liquid, or in the solid state in combination with other materials such as metal hydrides and carbon materials.

Storing hydrogen in its gaseous state is very common and forms the simplest and most efficient solution in terms of fast filling-releasing rate. To increase its density, the gaseous hydrogen is normally compressed and store at pressures between $35 \mathrm{MPa}$ and $70 \mathrm{MPa}$ [66]. Despite that increasing the storage pressure seems to be an advantage for low-density gaseous hydrogen, the temperature rise during the fuel filling becomes a major challenge at very high pressures [67]. Metallic tanks, such as steel, are normally used for gaseous hydrogen storage. However, the pure hydrogen at high pressure may have serious deleterious effects on the mechanical properties of metals such as promoting localised plastic processes and accelerating crack propagation rate [67]. Today, tanks made of composite material, as shown in Figure 3, are increasingly employed for storing hydrogen. Such tanks are light in weight and can withstand high pressures and thus they are very attractive for transportation applications as in 
aircraft. The tank consists of a high-density polyethene liner wrapped with carbon fibres composites shell. However, composite tanks are generally expensive with price tags between 500-600 USD/Kg H 2 [59]. Also, hydrogen compatibility and durability of composite vessels with polymeric liner still require further research and validation.

Hydrogen can be stored as a liquid in cryogenic tanks. Hydrogen needs first to be liquefied at $-253{ }^{\circ} \mathrm{C}$ and this process consumes up to $40 \%$ of the chemical energy stored in the hydrogen. A cryogenic vessel, shown in Figure 4, uses a very complex vacuum insulation technique consisting of approximately 40 layers of metal foil to maintain the temperature of $-253{ }^{\circ} \mathrm{C}$ for the hydrogen in the tank and limiting the boil-off loses [68]. $\mathrm{LH}_{2}$ is difficult to store for long period as up to $3 \%$ of hydrogen is lost on daily basis due to evaporation caused by the heat gain from surroundings. The main factors that affect boil-off loses, i.e. loses due to evaporation of $\mathrm{LH}_{2}$, are the geometry of the vessel, thermal insulation, the ambient conditions, quantity of hydrogen and the length of storage time. The materials that can be used to construct a cryogenic tank wall should have high strength, high fracture toughness, low density and low permeation to both liquid and gaseous hydrogen. Fracture toughness property is of particular importance as many materials become brittle at the cryogenic temperatures [69]. The density of cryogenic hydrogen is $70.8 \mathrm{~kg} / \mathrm{m} 3$ which is almost twice the density of pressurised hydrogen gas. The high density of the $\mathrm{LH}_{2}$ is the key feature that allowing using this storage technique for various aerospace applications whether at subsonic or hypersonic speeds [19]. The Boeing unmanned aerial system, Phantom Eye, employed lightweight cryogenic hydrogen tank to power hydrogen internal combustion engines [70].

The final storage method of hydrogen is to store it chemically in the solid state as in metal hydrides such as $\mathrm{Mg}_{2} \mathrm{NiH}_{4}, \mathrm{FeTiH}_{1.95}, \mathrm{LaNi}_{5} \mathrm{H}_{6.7}$, or in chemical hydride such as alkali metals borohydrides $\left(\mathrm{LiBH}_{4}\right.$ or $\left.\mathrm{NaBH}_{4}\right)$. In this technique, the hydrogen is first absorbed reversibly by solid compounds, such as $\mathrm{Li}, \mathrm{Na}, \mathrm{Mg}$, Ti, under certain temperature and pressure conditions 
and then it can be released when needed to by increasing its temperature or decreasing the operating pressure. The hydrogen content in metal hydrides is around $7.6 \mathrm{wt} \%$ while it reaches $18.4 \mathrm{wt} \%$ in borohydrides [68], [71]. The main demerit of chemical hydride is the need to convert the by-products of the chemical reaction off-board in a suitable location [66]. The chemical storage technology, using sodium borohydride $\mathrm{NaBH}_{4}$, was tested by Korea Advanced Institute of Science and Technology to obtain 5 hour flight time for a blended wing body micro air vehicle (MAV) combined with two $25 \mathrm{~W}$ fuel cells. It was proved that the propulsion system made of a fuel cell with $\mathrm{NaBH}_{4}$ tank can provide an energy density of 1000 $\mathrm{Wh} / \mathrm{kg}[52]$.

A comparison of hydrogen storage methods is shown in Table 4 and Table 5. Generally, for the aviation and aerospace applications, cryogenic tanks that can store $\mathrm{LH}_{2}$ continue to remain the most attractive storage method as it provides high hydrogen content for low weight and reasonable volume capacities. Hydride and gaseous storage methods are impractical because of the excessive weight or volume of the tanks [69].

\section{Role of hydrogen technology in a sustainable aviation economy}

Aviation continues to remain one of the hardest sectors to decarbonise [40]. Airports around the world face several challenges related to the quality of air, noise pollution, and energy efficiency [72]. Additionally, airports operations need to handle thousands of travellers and aircraft on a daily basis and this makes the balancing between such intensive operations and their impact on the environment more complex than ever. The contribution of the aviation industry to global $\mathrm{CO}_{2}$ emissions has received increased interest in the last two decades [73]. The main target of the aviation industry worldwide is to achieve $50 \%$ reduction in the net $\mathrm{CO}_{2}$ emissions by 2050 compared to 2005 levels [74]. Thus, in order to achieve such ambitious target, more sustainable energy resources and technologies, such as jet biofuels [74], hybrid propulsion systems [75], and hydrogen energy [3], are required to be deployed in the sector. 
Hydrogen and fuel cell technologies have a great potential to tackle the challenges of ensuring a cleaner future for the aviation industry. Hydrogen as a jet fuel provides many advantages over kerosene such as higher specific energy, less operating and engine maintenance costs, zero $\mathrm{CO}_{2}$ emissions and less NOx emissions [17]. Additionally, using fuel cell technology to power various airport vehicles and equipment will mitigate the impact of pollution and enhance the quality air around the airports.

Currently, hydrogen is only produced economically using natural gas reformation process which cannot completely solve the issues of air pollution and sustainability [76], [77]. Satisfying the economic and environmental requirements of adoption hydrogen for aviation sector requires that the majority of hydrogen should be produced from a clean energy source without the need to construct a long network of pipelines to transmit it from the production sites to the consumption centres. This can be achieved by producing hydrogen in locations close to the airports using renewable energy sources such as bioenergy, wind, geothermal, solar, and ocean [78], [79]. Andrews and Shabani [78] have identified three principal types of clean hydrogen production centres that can be used to produce hydrogen from different renewable energy sources including coastal hydrogen centres (CHCs), off-shore hydrogen centres (OHCs), inland hydrogen centres (IHCs). CHCs and OHCs use wave, wind, and/or tidal stream to produce electricity which then can be used in electrolysers to produce hydrogen from seawater. IHCs can employ other renewable energy sources such as solar radiation, solar thermal systems, wind power, and biomass resources to generate hydrogen. Thus, the type of renewable energy sources that can be used in a specific airport for hydrogen production purposes depends mainly on the location of the airport. Airports located close to a coastal region might use the wave and wind energy while those inland airports could rely more on the solar and bioenergy to produce hydrogen. Many airports across the world have already constructed hydrogen fuelling stations to supply hydrogen for fuel cell vehicles such as those 
in Berlin airport [80], Oslo airport [81], Orly Airport Paris [82], and Narita International Airport [83]. The Berlin airport hydrogen facility produces hydrogen on-site via electrolysis using solar and wind energy [80].

\section{Challenges and future developments of hydrogen technology in the aviation industry}

The aviation community continues to face complex challenges in using hydrogen and fuel cell technologies for the various applications in the sector. On the large scale, there is a lack of infrastructure required to provide the hydrogen fuel, as an energy carrier, for the aviation industry. The transition to hydrogen-powered aircraft will not only alter the aircraft design but also the airport operations. Special refuelling and storage structures will be required for handling and storing $\mathrm{LH}_{2}$ in the airports. The temperature of $\mathrm{LH}_{2}$ should be kept below $25 \mathrm{~K}$ and for this tanks with excellent insulation have to be built in the airports. Also, the airports will need special trucks with insulated fuel tanks for refuelling the aircraft with $\mathrm{LH}_{2}$. Additionally, refuelling process of hydrogen-powered aircraft is more complex and takes longer time than the traditional one due to high risk of hydrogen leaking during the process [17]. Thus, very strict safety regulations are required to control any hydrogen leaking issue. Such problems can only be addressed by the respective international authorities who need to develop proper hydrogen fuel infrastructures and safety regulations after reaching a consensus regarding the transition to hydrogen utilisation for civilian transport applications [18].

Among the other challenges is the ability to produce high-quality hydrogen in a costeffective manner and deliver it safely to the end users. One of the major problems in the production of hydrogen is its quality for any specific demand. For example, PEMFCs use platinum catalyst for the electrochemical reaction. This catalyst can easily be poisoned by any impurity in the hydrogen and this reduces its efficiency [40]. Therefore, hydrogen production technologies must be able to produce pure hydrogen or a purification process will be needed 
and this will increase the overall cost of the hydrogen. The effects of hydrogen impurity on fuel cell performance could be reduced by using cost-effective non-platinum catalysts such as molybdenum nitride (Mo2N/C), tungsten nitride (W2N/C), carbon/polyaniline/cobalt (C-PaniCo), iron acetate (FeAc), etc. These novel catalysts have received intensive research efforts in the past ten years. Detailed background about such catalysts is available elsewhere [84].

Another challenge is the cost of hydrogen production as the initial and operational costs of the majority of hydrogen production technologies are very high compared to other types of fuels [60]. Production of hydrogen using renewable energy sources, particularly for large-scale $\mathrm{LH}_{2}$ suitable for the aviation industry, is still more expensive and less attractive than the conventional conversion methods which have a greater environmental impact [62]. Redesign the production process, reducing its steps, and improving materials and equipment should help in reducing the high cost of hydrogen production. In terms of hydrogen transportation, the pipelines network responsible for hydrogen delivery should be made from special materials that can withstand the permeation effects of the hydrogen and resist the embrittlement caused by it.

Developing a light-weight, cost-effective, and safe hydrogen storage technology is another important requirement for the widespread commercialisation of hydrogen fuel cells technology in aviation applications. A light-weight hydrogen storage solution is needed for manned and unmanned vehicles. Among the various hydrogen storing technologies, only the cryogenic tank that store $\mathrm{LH}_{2}$ appears to be practical in the near future for the aviation industry. A tank that is suitable for aviation and aerospace applications differs significantly from those developed for ground applications. The tank's insulation should be designed to withstand excessive thermal loads for longer time particularly in supersonic flight scenario and thus developing durable and light materials is very crucial for the success of the storing process. 
Effective burning of hydrogen as jet fuel requires redesigning the traditional combustion chamber. The hydrogen has higher flame speed, larger diffusivity, and larger range of flammability compared to kerosene [19]. Thus, a conventional combustion chamber with a limited number of injectors is not suitable for burning hydrogen as it does not allow for a full mixing of air and hydrogen leading to the formation of greater amounts of NOx pollutants [19].

The low power density, i.e. power per unit mass, of the fuel cell devices, particularly those that need a big BoP such as SOFC, is the main challenge facing the use of fuel cell device on board of aircraft. Fuel cell must have a power density of $1 \mathrm{~kW} / \mathrm{kg}$ to be feasible to be used onboard of an aircraft [85]. Using a heavy fuel cell onboard of aircraft increases the weight of the aircraft and this result in greater fuel consumption as well as greater emissions produced by the aircraft. The integration of the fuel cell with its BoP into the aircraft is a major problem and requires modifying the current aircraft configuration [18].

\section{Conclusion}

The aviation sector is considered as a major contributor to the total GHG emissions. Burning Kerosene, which is the conventional jet fuel, produces $2-3 \%$ of all global $\mathrm{CO}_{2}$ emissions and thus the high dependency on fossil commodities in the aviation sector should be critically reviewed. Hydrogen has been considered as a promising clean replacement of the convention jet fuel that is capable of reducing the environmental impact resulted from the aviation industry. However, the high cost of hydrogen production technologies via renewable source, lack of hydrogen fuel infrastructure, hydrogen storage issues, and the need to change the layout of the aircraft have contributed to slowing the developing of hydrogen-powered aircraft.

Fuel cell technology has also been studied to be used for powering different devices used in the aviation industry such as auxiliary power units of aircraft and ground support equipment in the airports. Using fuel cells APU provides many advantages including small engine size, low carbon emissions, and efficient energy conversion. Additionally, fuel cells have been 
developed to be used as an alternative to batteries in unmanned aerial vehicles. Fuel cells have successfully allowed for increasing the range of small UAVs compared to those powered by a battery. However, all of the fuel-cell-powered aircraft are limited to small light aircraft with short range flight and not for long-range flight. Also, the various types of fuel cell devices have found a big usage in space vehicles for power generation and energy storage applications.

Despite the technology has attained massive breakthroughs in recent years, there is still a need to solve various issues before seeing a full integration of the fuel cell technology in the aviation sector. Improvements in fuel cell design and hydrogen storage tanks make fuel cell technology more viable for aerospace applications. Understanding fuel cell performance under extreme conditions such as low pressure, low gravity, and low temperature is also essential to develop efficient devices for aerospace applications. Finally, increasing the power density, reducing the cost and extending the lifetime of the fuel cells are also important factors that might accelerate the marriage between the technology and the aviation applications.

\section{References}

[1] “Air | Mobility and Transport." [Online]. Available: https://ec.europa.eu/transport/modes/air_en. [Accessed: 26-Jan-2019].

[2] “Current market outlook 2017-2036." [Online]. Available: http://www.boeing.com/resources/boeingdotcom/commercial/market/current-marketoutlook-2017/assets/downloads/2017-cmo-6-19.pdf. [Accessed: 05-May-2018].

[3] M. Gizem Sürer and H. Turan Arat, "State of art of hydrogen usage as a fuel on aviation,” Eur. Mech. Sci., vol. 2, no. 1, pp. 20-30, 2018.

[4] Y. Bicer and I. Dincer, "Life cycle evaluation of hydrogen and other potential fuels for aircrafts," Int. J. Hydrogen Energy, vol. 42, no. 16, pp. 10722-10738, Apr. 2017.

[5] "Facts and Figures, Air Transport Action Group, May 2018." [Online]. Available: https://www.atag.org/facts-figures.html. [Accessed: 05-May-2018]. 
[6] C. Koroneos, A. Dompros, G. Roumbas, and N. Moussiopoulos, "Life Cycle Assessment of Kerosene Used in Aviation (8 pp)," Int. J. Life Cycle Assess., vol. 10, no. 6, pp. 417-424, Nov. 2005.

[7] T. Wilberforce, A. Alaswad, A. Palumbo, and M. Dassisti, "Advances in stationary and portable fuel cell applications," Int. J. Hydrogen Energy, vol. 41, no. 37, pp. $16509-16522,2016$.

[8] A. Alaswad, A. Baroutaji, H. Achour, J. Carton, A. Al Makky, and A. G. Olabi, "Developments in fuel cell technologies in the transport sector," Int. J. Hydrogen Energy, vol. 41, no. 37, pp. 16499-16508.

[9] T. Wilberforce, Z. El-Hassan, F. N. Khatib, A. Al Makky, A. Baroutaji, J. G. Carton, and A. G. Olabi, "Developments of electric cars and fuel cell hydrogen electric cars," Int. J. Hydrogen Energy, vol. 42, no. 40, pp. 25695-25734, 2017.

[10] T. Wilberforce, A. A. A. A. Makky, A. Baroutaji, R. Sambi, and A. G. G. Olabi, “Computational Fluid Dynamic simulation and modelling (CFX) of flow plate in PEM fuel cell using aluminum open cellular foam material," 2017, pp. 1-6.

[11] T. Wilberforce, Z. El-Hassan, F. N. Khatib, A. Al Makky, A. Baroutaji, J. G. J. G. Carton, J. Thompson, and A. G. A. G. Olabi, "Modelling and simulation of Proton Exchange Membrane fuel cell with serpentine bipolar plate using MATLAB," Int. J. Hydrogen Energy, vol. 42, no. 40, pp. 25639-25662, Oct. 2017.

[12] T. Wilberforce, Z. El-Hassan, F. N. Khatib, A. Al Makky, J. Mooney, A. Baroutaji, J. G. Carton, and A.-G. Olabi, "Development of Bi-polar plate design of PEM fuel cell using CFD techniques," Int. J. Hydrogen Energy, vol. 42, no. 40, pp. 25663-25685, Oct. 2017.

[13] A. Baroutaji, J. G. Carton, J. Stokes, and A. G. Olabi, “Application of Open Pore Cellular Foam for air breathing PEM fuel cell," Int. J. Hydrogen Energy, vol. 42, no. 
40, pp. 25630-25638, Oct. 2017.

[14] A. Baroutaji, J. G. Carton, M. Sajjia, and A. G. Olabi, "Materials in PEM Fuel Cells," in Reference Module in Materials Science and Materials Engineering, Saleem Hashmi (editor-in-chief), Ed. Oxford: Elsevier, 2016, pp. 1-11.

[15] J. G. Carton and A. Baroutaji, "Developments of Foam Materials for Fuel Cell Technology," in Reference Module in Materials Science and Materials Engineering, Elsevier, 2016.

[16] A. Baroutaji, J. Carton, J. Stokes, and A.-G. Olabi, "Design and development of proton exchange membrane fuel cell using open pore cellular foam as flow plate material," Journal of Energy Challenges and Mechanics. North Sea Conference \& Journal LTD, 06-Sep-2014.

[17] E. Baharozu and G. Soykan, "Future aircraft concept in terms of energy efficiency and environmental factors," Energy, vol. 140, pp. 1368-1377, Dec. 2017.

[18] I. Dincer and C. Acar, "A review on potential use of hydrogen in aviation applications," Int. J. Sustain. Aviat., vol. 2, no. 1, p. 74, 2016.

[19] D. Cecere, E. Giacomazzi, and A. Ingenito, "A review on hydrogen industrial aerospace applications," Int. J. Hydrogen Energy, vol. 39, no. 20, pp. 10731-10747, Jul. 2014.

[20] “Space Applications of Hydrogen and Fuel Cells," 2017. [Online]. Available: https://www.nasa.gov/content/space-applications-of-hydrogen-and-fuel-cells. [Accessed: 05-May-2018].

[21] D. Verstraete, "Long range transport aircraft using hydrogen fuel," Int. J. Hydrogen Energy, vol. 38, no. 34, pp. 14824-14831, Nov. 2013.

[22] D. S. Lee, G. Pitari, V. Grewe, K. Gierens, J. E. Penner, A. Petzold, M. J. Prather, U. Schumann, A. Bais, T. Berntsen, D. Iachetti, L. L. Lim, and R. Sausen, “Transport 
impacts on atmosphere and climate: Aviation," Atmos. Environ., vol. 44, no. 37, pp. 4678-4734, Dec. 2010.

[23] A. Contreras, S. Yiğit, K. Özay, and T. N. Veziroğlu, "Hydrogen as aviation fuel: A comparison with hydrocarbon fuels," Int. J. Hydrogen Energy, vol. 22, no. 10-11, pp. 1053-1060, Oct. 1997.

[24] O. Wild, M. J. Prather, and H. Akimoto, "Indirect long-term global radiative cooling from NOx Emissions," Geophys. Res. Lett., vol. 28, no. 9, pp. 1719-1722, May 2001.

[25] B. Khandelwal, A. Karakurt, P. R. Sekaran, V. Sethi, and R. Singh, "Hydrogen powered aircraft: The future of air transport," Prog. Aerosp. Sci., vol. 60, pp. 45-59, Jul. 2013.

[26] M. Talibi, P. Hellier, R. Balachandran, and N. Ladommatos, "Effect of hydrogendiesel fuel co-combustion on exhaust emissions with verification using an in-cylinder gas sampling technique," Int. J. Hydrogen Energy, vol. 39, no. 27, pp. 15088-15102, Sep. 2014.

[27] D. Verstraete, "The Potential of Liquid Hydrogen for long range aircraft propulsion," 2009.

[28] J. E. Sharpe, N. Bimbo, V. P. Ting, B. Rechain, E. Joubert, and T. J. Mays, "Modelling the potential of adsorbed hydrogen for use in aviation," Microporous Mesoporous Mater., vol. 209, pp. 135-140, Jun. 2015.

[29] H. Nojoumi, I. Dincer, and G. F. Naterer, "Greenhouse gas emissions assessment of hydrogen and kerosene-fueled aircraft propulsion," Int. J. Hydrogen Energy, vol. 34, no. 3, pp. 1363-1369, Feb. 2009.

[30] D. Verstraete, "On the energy efficiency of hydrogen-fuelled transport aircraft," Int. J. Hydrogen Energy, vol. 40, no. 23, pp. 7388-7394, Jun. 2015.

[31] G. F. Eberle and M. D. Steer, "Air Quality Procedures for Civilian Airports and Air 
Force Bases," Washington DC, 1982.

[32] "Emerging Fuel Cell Technology Being Developed--Offers Many Benefits to Air Vehicles."

[33] J. Bayer, "Fuel Cell Airport/Aviation Challenges And Opportunites," in Aviation Operational Measures for Fuel and Emission Reduction Workshop, 2002.

[34] M. D. Fernandes, S. T. de P. Andrade, V. N. Bistritzki, R. M. Fonseca, L. G. Zacarias, H. N. C. Gonçalves, A. F. de Castro, R. Z. Domingues, and T. Matencio, "SOFC-APU systems for aircraft: A review,” Int. J. Hydrogen Energy, vol. 43, no. 33, pp. 1631116333, Aug. 2018.

[35] S. Eelman, de Poza, and T. Krieg, "Fuel cell APU'S in commercial aircraft - an assessment of SOFC and PEMFC concepts," in 24th international congress of aeronautical sciences, 2004.

[36] B. Law, “The Airbus Fuel Cell Approach.” [Online]. Available: http://www.bbabw.de/files/brennstoffzelle_im_flugzeug_-_law_121023.pdf. [Accessed: 05-May2016].

[37] JAY SPENSER, "Fuel cells in the air." [Online]. Available: http://www.boeing.com/news/frontiers/archive/2004/july/ts_sf7a.html. [Accessed: 05May-2018].

[38] Boeing., "Commercial Airplanes - Fuel Cell APU Overview," in SECA Annual Meeting, 2003.

[39] J. Dunn, "Fuel Cell Electric Aircraft Energy Challenge New Era of Aviation," in Electric Aircraft Symposium, 2007.

[40] I. Staffell, D. Scamman, A. Velazquez Abad, P. Balcombe, P. E. Dodds, P. Ekins, N. Shah, and K. R. Ward, "The role of hydrogen and fuel cells in the global energy system,” Energy Environ. Sci., 2019. 
[41] "Non-Road Mobile Machinery Usage, Life and Correction Factors,” 2004. [Online]. Available: https://ukair.defra.gov.uk/assets/documents/reports/cat15/0502141215_NRMM_report_Final_N ovember_2004_3.pdf. [Accessed: 05-May-2018].

[42] "DOE funds to deploy fuel cells for baggage vehicles at airports," Fuel Cells Bull., vol. 2012, no. 5, pp. 3-4, May 2012.

[43] V. P. McConnell, "Fuel cells in forklifts extend commercial reach," Fuel Cells Bull., vol. 2010, no. 9 , pp. 12-19, Sep. 2010.

[44] “Fuel cell forklift from German partnership," Fuel Cells Bull., vol. 2003, no. 12, p. 9, Dec. 2003.

[45] "Plug Power, FedEx project rolls out fuel cell airport tractors," Fuel Cells Bull., vol. 2015, no. 5, pp. 2-3, May 2015.

[46] “Toyota, Hino deliver fuel cell bus for Haneda airport route in Tokyo," Fuel Cells Bull., vol. 2011, no. 1, p. 3, Jan. 2011.

[47] "US Hybrid, BYD to develop fuel cell bus for Honolulu Airport," Fuel Cells Bull., vol. 2018, no. 6, p. 2, Jun. 2018.

[48] N. Belmonte, S. Staulo, S. Fiorot, C. Luetto, P. Rizzi, and M. Baricco, "Fuel cell powered octocopter for inspection of mobile cranes: Design, cost analysis and environmental impacts," Appl. Energy, vol. 215, pp. 556-565, Apr. 2018.

[49] "Fuel cell and hybrid power systems offer compelling value for UAVs whose missions demand greater runtime than batteries can support." [Online]. Available: http://www.ballard.com/markets/uav. [Accessed: 05-May-2018].

[50] “AeroVironment flies world's first hydrogen powered plane," Fuel Cells Bull., vol. 2005, no. 9, pp. 2-3, Sep. 2005.

[51] T. H. Bradley, B. A. Moffitt, D. N. Mavris, and D. E. Parekh, "Development and 
experimental characterization of a fuel cell powered aircraft," J. Power Sources, vol. 171, no. 2, pp. 793-801, Sep. 2007.

[52] A. Gong and D. Verstraete, "Fuel cell propulsion in small fixed-wing unmanned aerial vehicles: Current status and research needs," Int. J. Hydrogen Energy, vol. 42, no. 33, pp. 21311-21333, Aug. 2017.

[53] T. Kim and S. Kwon, "Design and development of a fuel cell-powered small unmanned aircraft,” Int. J. Hydrogen Energy, vol. 37, no. 1, pp. 615-622, Jan. 2012.

[54] "Boeing fuel cell plane in manned aviation first," Fuel Cells Bull., vol. 2008, no. 4, p. 1, Apr. 2008.

[55] "First flight of DLR's HY4 fuel cell light aircraft," Fuel Cells Bull., vol. 2016, no. 10, p. 1, Oct. 2016.

[56] "NASA - Fuel Cell Use in the Space Shuttle.” [Online]. Available: https://www.nasa.gov/topics/technology/hydrogen/fc_shuttle.html. [Accessed: 05May-2018].

[57] K. A. Burke, "Fuel Cells for Space Science Applications," Cleveland, Ohio, 2003.

[58] B. J. Crowe, "FUEL CELLS A SURVEY."

[59] International Energy Agency, "Hydrogen Production and Storage. R\&D Priorities and Gaps,” 2006.

[60] F. C. \& F. Partnership, "Hydrogen production - Overview of technology options," 2009.

[61] O. Bičáková and P. Straka, "Production of hydrogen from renewable resources and its effectiveness," Int. J. Hydrogen Energy, vol. 37, no. 16, pp. 11563-11578, Aug. 2012.

[62] P. Stadler, "Cost evaluation of large scale hydrogen production for the aviation industry," 2014.

[63] F. Zhang, P. Zhao, M. Niu, and J. Maddy, "The survey of key technologies in 
hydrogen energy storage," Int. J. Hydrogen Energy, vol. 41, no. 33, pp. 14535-14552, Sep. 2016.

[64] "Hydrogen Production: Thermochemical Water Splitting | Department of Energy." [Online]. Available: https://www.energy.gov/eere/fuelcells/hydrogen-productionthermochemical-water-splitting. [Accessed: 27-Aug-2018].

[65] "Hydrogen Production: Biomass Gasification | Department of Energy." [Online]. Available: https://www.energy.gov/eere/fuelcells/hydrogen-production-biomassgasification. [Accessed: 27-Jan-2019].

[66] H. Barthelemy, M. Weber, and F. Barbier, "Hydrogen storage: Recent improvements and industrial perspectives," Int. J. Hydrogen Energy, vol. 42, no. 11, pp. 7254-7262, Mar. 2017.

[67] J. Zheng, X. Liu, P. Xu, P. Liu, Y. Zhao, and J. Yang, "Development of high pressure gaseous hydrogen storage technologies," Int. J. Hydrogen Energy, vol. 37, no. 1, pp. 1048-1057, Jan. 2012

[68] M. Felderhoff, C. Weidenthaler, R. von Helmolt, and U. Eberle, "Hydrogen storage: the remaining scientific and technological challenges," Phys. Chem. Chem. Phys., vol. 9, no. 21, p. 2643, May 2007.

[69] D. Verstraete, P. Hendrick, P. Pilidis, and K. Ramsden, "Hydrogen fuel tanks for subsonic transport aircraft," Int. J. Hydrogen Energy, vol. 35, no. 20, pp. 11085 11098, Oct. 2010.

[70] "Boeing: Phantom Eye." [Online]. Available: https://www.boeing.com/defense/phantom-eye/. [Accessed: 29-Aug-2018].

[71] I. P. Jain, C. Lal, and A. Jain, "Hydrogen storage in Mg: A most promising material," Int. J. Hydrogen Energy, vol. 35, no. 10, pp. 5133-5144, May 2010.

[72] “2007-2008 Hydrogen Design Contest: Hydrogen Applications for Airports Official 
Rules and Design Guidelines.”

[73] R. Blockley, W. Shyy, R. Agarwal, F. Collier, A. Schäfer, and A. Seabridge, Green aviation. .

[74] M. A. F. D. Moraes, A. M. Nassar, P. Moura, R. L. V. Leal, and L. A. B. Cortez, "Jet biofuels in Brazil: Sustainability challenges," Renew. Sustain. Energy Rev., vol. 40, pp. 716-726, Dec. 2014.

[75] C. Gonzalez, "The Future of Electric Hybrid Aviation," 2016. [Online]. Available: https://www.machinedesign.com/batteriespower-supplies/future-electric-hybridaviation. [Accessed: 02-Feb-2019].

[76] J. Brouwer, "On the role of fuel cells and hydrogen in a more sustainable and renewable energy future,” Curr. Appl. Phys., vol. 10, no. 2, pp. S9-S17, Mar. 2010.

[77] T. Wilberforce, A. Baroutaji, B. Soudan, A. H. Al-Alami, and A. G. Olabi, "Outlook of carbon capture technology and challenges," Sci. Total Environ., vol. 657, pp. 56-72, Mar. 2019.

[78] J. Andrews and B. Shabani, "Where does Hydrogen Fit in a Sustainable Energy Economy?," Procedia Eng., vol. 49, pp. 15-25, Jan. 2012.

[79] T. Wilberforce, A. Baroutaji, Z. El Hassan, J. Thompson, B. Soudan, and A. G. Olabi, "Prospects and challenges of concentrated solar photovoltaics and enhanced geothermal energy technologies," Sci. Total Environ., vol. 659, pp. 851-861, Apr. 2019.

[80] “Green hydrogen facility opens at Berlin airport," Fuel Cells Bull., vol. 2014, no. 5, p. 1, May 2014.

[81] "Norway opens new hydrogen station at Oslo Airport," Fuel Cells Bull., vol. 2015, no. 10, pp. 9-10, Oct. 2015.

[82] "Air Liquide, Groupe ADP hydrogen station at Paris-Orly Airport," Fuel Cells Bull., 
vol. 2018, no. 1, pp. 7-8, Jan. 2018.

[83] "Idemitsu opens its first commercial hydrogen station at Narita airport," Fuel Cells Bull., vol. 2016, no. 3, p. 8, Mar. 2016.

[84] R. Othman, A. L. Dicks, and Z. Zhu, "Non precious metal catalysts for the PEM fuel cell cathode," Int. J. Hydrogen Energy, vol. 37, no. 1, pp. 357-372, Jan. 2012.

[85] G. Whyatt and L. Chick, "Electrical Generation for More-Electric Aircraft using Solid Oxide Fuel Cells,”2012.

[86] H. T. Hwang and A. Varma, "Hydrogen storage for fuel cell vehicles," Curr. Opin. Chem. Eng., vol. 5, pp. 42-48, Aug. 2014.

[87] L. Schlapbach and A. Züttel, "Hydrogen-storage materials for mobile applications," Nature, vol. 414, no. 6861, pp. 353-358, Nov. 2001.

[88] R. von Helmolt and U. Eberle, "Fuel cell vehicles: Status 2007," J. Power Sources, vol. 165, no. 2, pp. 833-843, Mar. 2007.

[89] B. C. H. Steele and A. Heinzel, "Materials for fuel-cell technologies," Nature, vol. 414, no. 6861, pp. 345-352, Nov. 2001.

[90] J. L. Young, M. A. Steiner, H. Döscher, R. M. France, J. A. Turner, and T. G. Deutsch, "Direct solar-to-hydrogen conversion via inverted metamorphic multi-junction semiconductor architectures," Nat. Energy, vol. 2, no. 4, p. 17028, Apr. 2017.

[91] K. . Spencer, "Investigation of Potential Fuel Cell Use in Aircraft," 2013.

[92] “Ion Tiger UAV - Naval Technology.” [Online]. Available: https://www.navaltechnology.com/projects/ion-tiger-uav/. [Accessed: 30-Aug-2018]. 


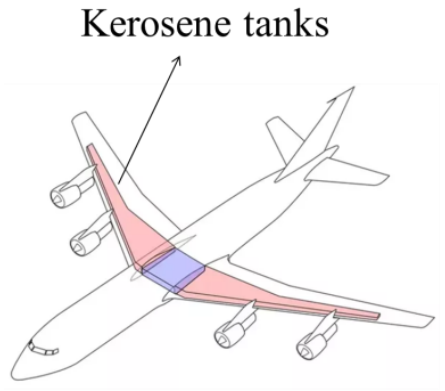

a

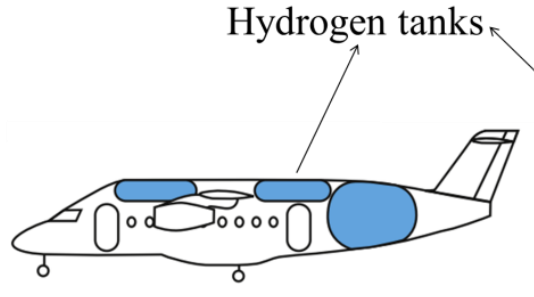

b

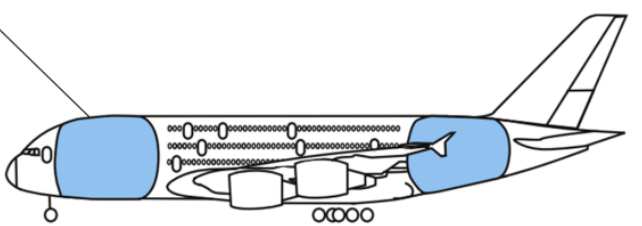

c

Figure 1: Fuel tank locations in (a) traditional and (b) medium rang hydrogen-powered aircrafts [69] (c) long rang hydrogen-powered aircrafts [69] 


\section{Hydrogen Storage}

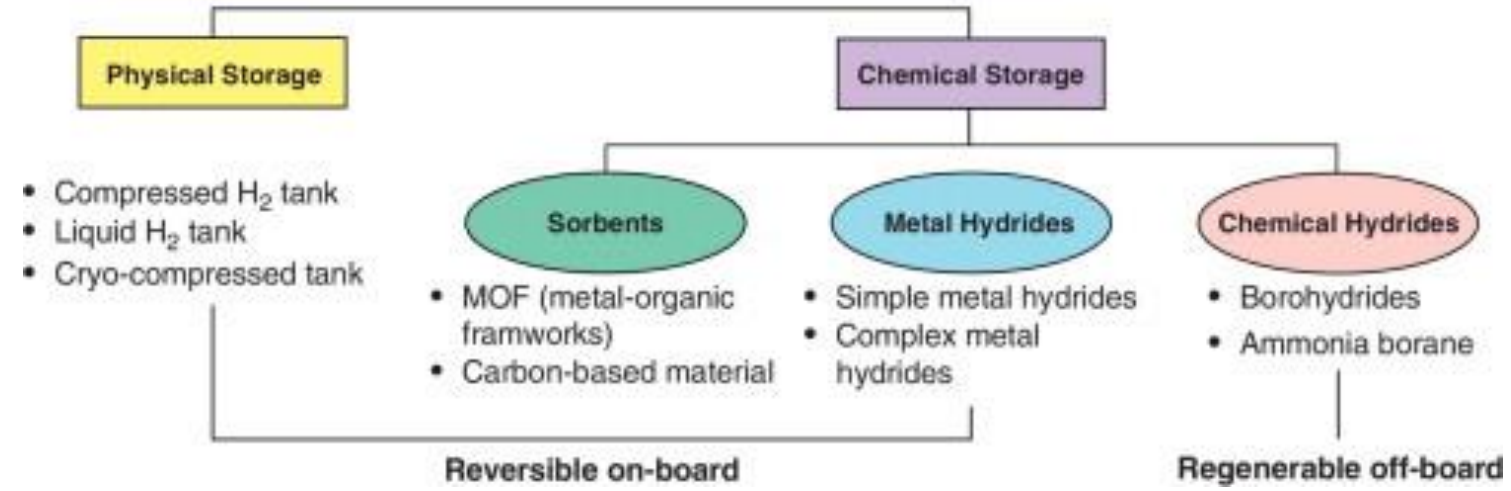

Figure 2: Hydrogen storage technologies [86] 


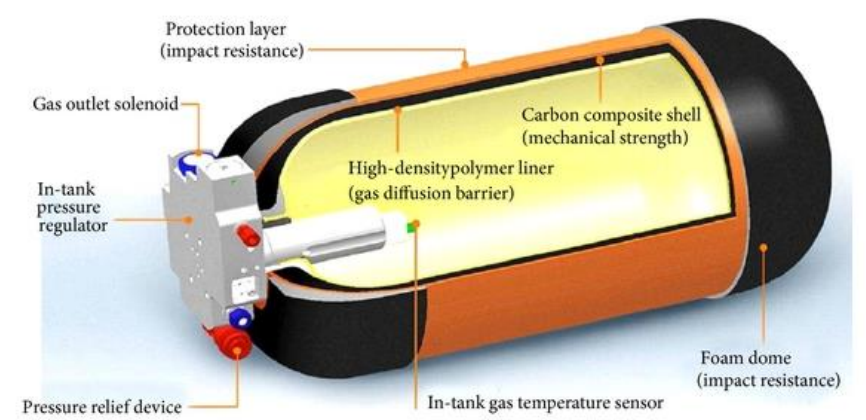

Figure 3: Composite tank for storing gaseous pressurised hydrogen [87] 


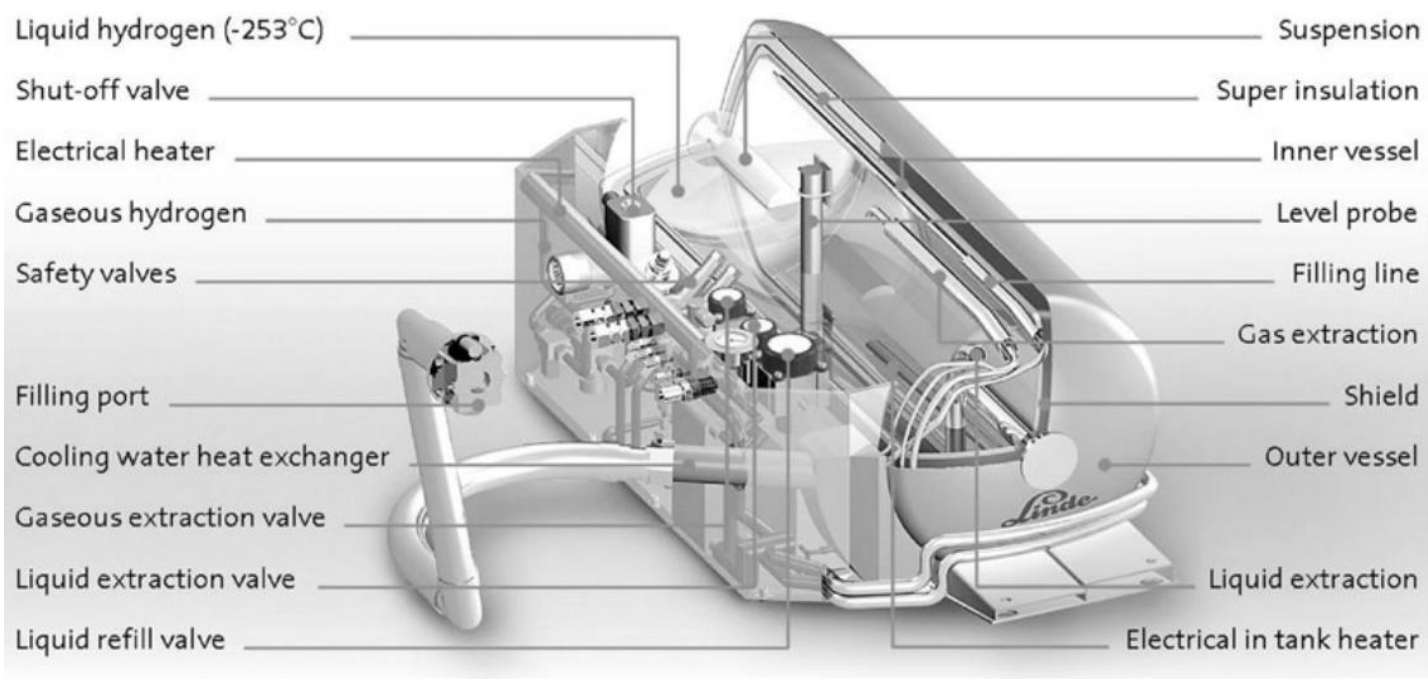

Figure 4: Liquid hydrogen vessel [88] 

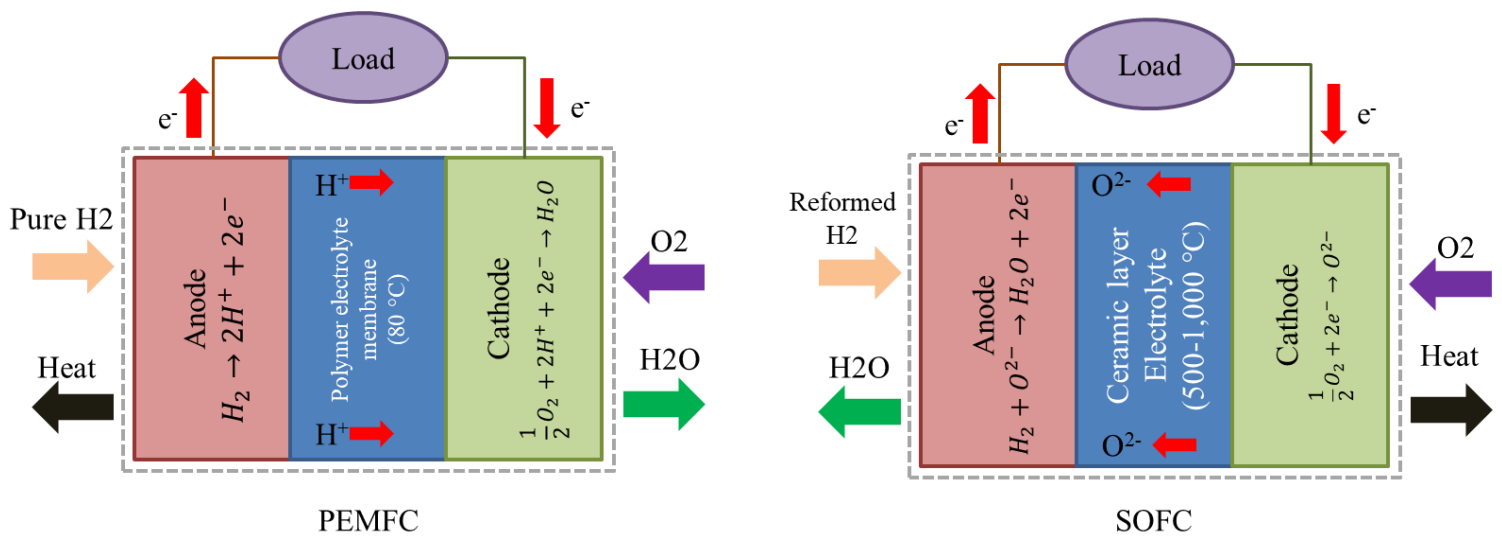

Figure 5: Summary of PEM and SOFC fel cells (Created based on information provided in [14], [89]. 
Table 1: Technologies used in hydrogen production

$$
\text { [40], [61], [90] }
$$

\begin{tabular}{|l|l|l|l|}
\hline Technology & Feedstock & Efficiency (\%) & Maturity \\
\hline Steam reforming & Hydrocarbons & $70-85$ & Commercial \\
\hline Partial oxidation & Hydrocarbons & $60-75$ & Commercial \\
\hline Plasma reforming & Hydrocarbons & $9-85$ & Long term \\
\hline Biomass gasification & Biomass & $35-50$ & Commercial \\
\hline Electrolysis & $\mathrm{H}_{2} \mathrm{O}+$ electricity & $50-$ bigger than 70 & Commercial \\
\hline Photolysis & $\mathrm{H}_{2} \mathrm{O}+$ sunlight & $0.5-16$ & Long term \\
\hline Thermochemical & $\mathrm{H}_{2} \mathrm{O}+$ Heat & Not applicable & Long term \\
water splitting & & & \\
\hline
\end{tabular}


Table 2: Comparison of the various technologies used

in hydrogen production [60]

\begin{tabular}{|c|c|c|c|c|}
\hline & Natural gas reforming & $\begin{array}{l}\text { Coal and biomass } \\
\text { gasification }\end{array}$ & Thermochemical & $\begin{array}{l}\text { Photo- } \\
\text { electrochemical }\end{array}$ \\
\hline $\begin{array}{l}\text { Main } \\
\text { Challenges }\end{array}$ & $\begin{array}{l}\text { - High maintenance and } \\
\text { operation costs } \\
\text { - Complex manufacturing } \\
\text { design } \\
\text { - The need for carbon } \\
\text { capture and storage } \\
\text { technology }\end{array}$ & $\begin{array}{l}\text { - The high cost of the } \\
\text { reactor } \\
\text { - Low efficiency of the } \\
\text { system } \\
\text { - Feedstock impurities } \\
\text { - The need for carbon } \\
\text { capture and storage } \\
\text { technology }\end{array}$ & $\begin{array}{l}\text { - The cost reactor is high } \\
\text { - Require effective and } \\
\text { durable material for } \\
\text { construction } \\
\text { - Longer term technology }\end{array}$ & $\begin{array}{l}\text { - Photocatalyst material } \\
\text { that is effective } \\
\text { - System efficiency is } \\
\text { low } \\
\text { - Require expensive } \\
\text { reactor } \\
\text { - Longer term technology }\end{array}$ \\
\hline Advantages & $\begin{array}{l}\text { - The best approach to start } \\
\text { the hydrogen market in } \\
\text { the near term } \\
\text { - Cheap current cost } \\
\text { - Feedstock infrastructure } \\
\text { is already in existence }\end{array}$ & $\begin{array}{l}\text { - Provide cheap } \\
\text { synthetic fuel in } \\
\text { addition to the } \\
\text { hydrogen. } \\
\text { - Uses abundant and } \\
\text { affordable hydrogen } \\
\text { coal feedstock }\end{array}$ & $\begin{array}{l}\text { - Generates hydrogen } \\
\text { using water, solar energy } \\
\text { or energy from nuclear } \\
\text { reactors and sometimes } \\
\text { chemicals that are } \\
\text { recycled } \\
\text { - Clean and sustainable }\end{array}$ & $\begin{array}{l}\text { - Functions only at low } \\
\text { temperature. } \\
\text { - Clean and sustainable } \\
\text { using only solar energy } \\
\text { and water }\end{array}$ \\
\hline
\end{tabular}


Table 3: Possible research activities for hydrogen production technologies [60]

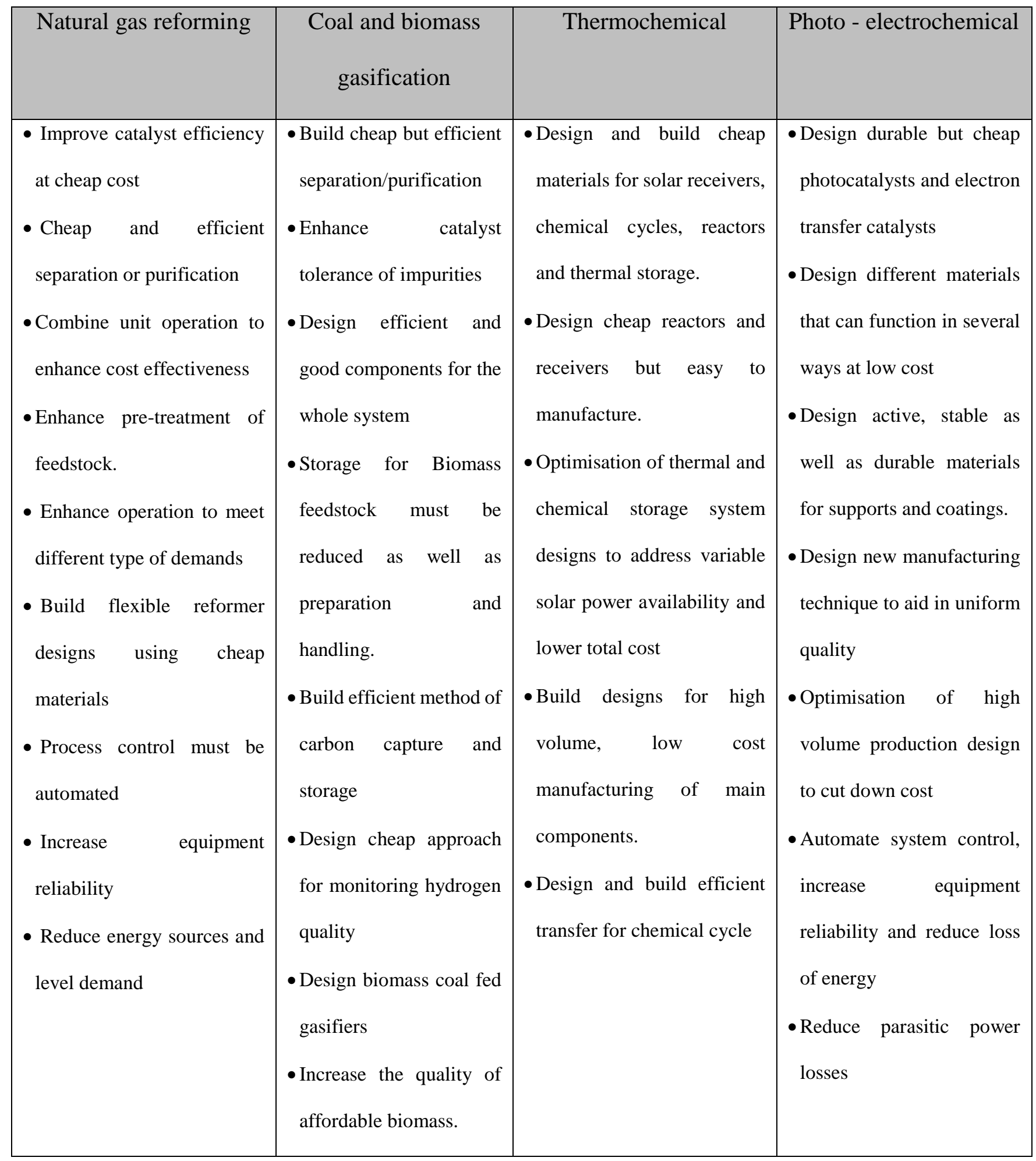


Table 4: Advantages and disadvantages of hydrogen storage techniques [86]

\begin{tabular}{|c|c|c|}
\hline Method & Advantages & Disadvantages \\
\hline Pressurised tanks & $\begin{array}{l}\text { - Simple and efficient } \\
\text { - Fast filling-releasing rate } \\
\text { - Commercially available }\end{array}$ & $\begin{array}{l}\text { - Low volumetric capacity } \\
\text { - High energy consumption } \\
\text { for compression the } \\
\text { hydrogen } \\
\text { - Heat management during } \\
\text { charging required } \\
\text { - High pressure tanks involves } \\
\text { various risks such as vessel } \\
\text { explosion, gas leakage, and } \\
\text { temperature rise }\end{array}$ \\
\hline Cryogenic tanks & $\begin{array}{l}\text { - High hydrogen content } \\
\text { - Commercially available }\end{array}$ & $\begin{array}{l}\text { - Hydrogen loss due to boil- } \\
\text { off } \\
\text { - Safety issues } \\
\text { - High energy consumption } \\
\text { for liquefying the hydrogen } \\
\text { - Thermal management system } \\
\text { is required for hydrogen } \\
\text { release and for reducing } \\
\text { boil-off losses }\end{array}$ \\
\hline Metal hydrides & - Low volume of the tank & $\begin{array}{l}\text { - Excessive weight of the tank } \\
\text { - High operating temperature } \\
\text { for hydrogen release } \\
\text { - Thermal management system } \\
\text { is required for hydrogen } \\
\text { release }\end{array}$ \\
\hline Chemical hydrides & $\begin{array}{l}\text { - Generate hydrogen with very } \\
\text { high purity } \\
\text { - Good volumetric capacity }\end{array}$ & $\begin{array}{l}\text { - Thermal management is } \\
\text { required } \\
\text { - Off-board regeneration } \\
\text { - The regeneration efficiency } \\
\text { is low }\end{array}$ \\
\hline
\end{tabular}


Table 5: Volume, weight and hydrogen content offered by some of hydrogen storage techniques [87]

\begin{tabular}{|c|c|c|c|}
\hline Hydrogen Storage technique & Volume (Litres) & Weight $(\mathrm{Kg})$ & Density [wt\% $\left.\mathrm{H}_{2}\right]$ \\
\hline $35 \mathrm{MPa}$ compressed $\mathrm{H}_{2}$ & 145 & 45 & 6.7 \\
\hline $70 \mathrm{MPa}$ compressed $\mathrm{H}_{2}$ & 100 & 50 & 6.0 \\
\hline Cryogenic liquid $\mathrm{H}_{2}$ & 90 & 40 & 7.5 \\
\hline Low temperature metal hydride & 55 & 215 & 1.4 \\
\hline
\end{tabular}


Table 6: Comparison of Fuel-Cell-Powered UAV

(Based on Ref [91], [92])

\begin{tabular}{|c|c|c|c|}
\hline Organization (date) & Fuel Cell Type & $\begin{array}{c}\text { Reactant Storage } \\
\text { Type }\end{array}$ & Endurance (est.) \\
\hline $\begin{array}{l}\text { AeroVironment } \\
\text { (2003) }\end{array}$ & PEM & $\begin{array}{l}\text { H2 Sodium } \\
\text { Borohydride }\end{array}$ & $0.2 \mathrm{hr}$ \\
\hline $\begin{array}{l}\text { AeroVironment } \\
\text { (2005) }\end{array}$ & PEM & H2 Cryogenic & $24 \mathrm{hr}$ \\
\hline $\begin{array}{c}\text { FH Wiesbaden } \\
(2005)\end{array}$ & PEM & H2 Gaseous & $90 \mathrm{~s}$ \\
\hline $\begin{array}{l}\text { Naval Research } \\
\text { Lab (2006) }\end{array}$ & PEM & H2 Gaseous & $3.3 \mathrm{hr}$ \\
\hline $\begin{array}{l}\text { Adaptive Materials } \\
\text { Inc. (2006) }\end{array}$ & SOFC & Propane & $4 \mathrm{hr}$ \\
\hline $\begin{array}{l}\text { Georgia Inst. of } \\
\text { Tech. (2006) }\end{array}$ & PEM & H2 Gaseous & $0.75 \mathrm{hr}$ \\
\hline $\begin{array}{l}\text { CSU Los Angeles } \\
\text { (2006) }\end{array}$ & PEM & H2 Gaseous & $0.75 \mathrm{hr}$ \\
\hline $\begin{array}{c}\text { DLR/HyFish } \\
(2006)\end{array}$ & PEM & H2 Gaseous & $0.25 \mathrm{hr}$ \\
\hline $\begin{array}{l}\text { CSULA/OSU } \\
(2007)\end{array}$ & PEM & H2 Gaseous & $12 \mathrm{hr}$ \\
\hline KAIST (2007) & PEM & $\begin{array}{l}\text { H2 Sodium } \\
\text { Borohydride }\end{array}$ & $10 \mathrm{hr}$ \\
\hline $\begin{array}{c}\text { AeroVironment } \\
(2007)\end{array}$ & PEM & $\begin{array}{l}\text { H2 Sodium } \\
\text { Borohydride }\end{array}$ & $9 \mathrm{hr}$ \\
\hline $\begin{array}{c}\text { Naval Research } \\
\text { Laboratory- Ion } \\
\text { Tiger UAV } \\
(2009) \\
\end{array}$ & PEM & H2 Gaseous & $26 \mathrm{hr}$ \\
\hline $\begin{array}{c}\text { Naval Research } \\
\text { Laboratory- Ion } \\
\text { Tiger UAV } \\
\text { (2013) }\end{array}$ & PEM & H2 Cryogenic & $48 \mathrm{hr}$ \\
\hline
\end{tabular}

